\title{
Hjelpeyrkenes to verdener
}

\author{
Kan ledere og politikere - eller forskere - egentlig fullt ut forstå det som skjer der hvor profesjonell hjelp rent \\ fysisk utføres? For mange kan det nok noen ganger fortone seg som om disse aktørene lever i en annen ver- \\ den enn praktikernes. Det er åpenbart en forskjell mellom en kroppslig erfaring og en mer abstrakt forstå- \\ else ved hjelp av ord. Kanskje stikker praksisen å hjelpe andre dypere i våre sinn enn aktiviteter som uteluk- \\ kende styres av plandokumenter?
}

Dag Gjerløw Aasland

dag.g.aasland@uia.no

I sin bok Om våren skriver Karl Ove Knausgård:

«Oftere og oftere foresvever det meg at vi lever i to virkeligheter, én fysisk, materiell, biologisk, kjemisk, det er tingenes og kroppenes verden, som vi kanskje kan kalle virkeligheten av første grad, og én abstrakt, immateriell, språklig og tankemessig, det er relasjonenes og det sosiales verden, som vi kan kalle virkeligheten av andre grad. Den første virkeligheten er styrt av ufravikelige lover, som ikke etterlater tvil - vannet fryser ved en bestemt temperatur, eplet løsner fra treet når det når en bestemt tyngde og vindkastet når en bestemt styrke, det faller ned mot bakken i en bestemt fart, og slaget mot bakken får kjøttet under skallet til å mykne i et bestemt mønster - mens den andre virkeligheten er relativ og forhandlingsbar. Dette hadde jo vært enkelt og overskuelig dersom verdenene hadde eksistert side om side, men slik er det jo ikke. Den ene verden eksisterer inne i den andre ...» $(1$, s. 69).

Dette kan vi si er en litterær variant av det som filosofen Edmund Husserl (1859-1938) fant det nødvendig å påpeke i sin bok om «krisen i de europeiske vitenskaper», som ble utgitt like etter hans død i 1938. Husserl regnes som grunnleggeren av fenomenologien, som tar utgangspunkt $i$ at vi mennesker bare kan beskrive verden slik den fremstår for oss som bevisste subjekter. Ingen kan påberope seg å kunne beskrive en objektivt gitt verden, «slik den er». På sine eldre dager ble Husserl bekymret for at vitenskapene, også videreføringene av hans egen fenomenologi, ble stadig mer lukket inne i sine egne teorier. For selv om den objektivt gitte virkeligheten ikke er direkte tilgjengelig for vitenskapene, må vi ikke late som om den ikke finnes:

«... den verden som omgir oss til daglig er antatt på forhånd å eksistere - den verden som vi alle (også jeg som nå filosoferer) er oss bevisste at vi eksisterer i. Her finnes også vitenskapene, som kulturelle fakta i den samme verden, med sine forskere og teorier. I denne verden er vi objekter blant andre objekter, med «verden» da i betydningen livsverden, det vil si som værende her og der, med en ren og umiddelbar erfaring, før noe er etablert vitenskapelig, enten det er i fysiologi, psykologi eller sosiologi. På den annen side er vi subjekter overfor denne verden, nemlig som jeg-subjekter som erfarer den, tenker på den, vurderer den og forholder oss til den med våre formål; ...» $(2$, s. $104-5$, min oversettelse $)$.

Som vi ser, hevder både Knausgård og Husserl at den subjektive verden eksisterer inne $i$ den verden som er objektivt gitt. Hva innebærer egentlig det?

\section{«lngen kan påberope seg å kunne beskrive en objektivt gitt verden slik den er»}

Dette spørsmålet har vitenskapen fått mer innsikt i siden Husserls tid. Nå kan vi underbygge både Knausgårds og Husserls observasjoner med kunnskap om hvordan subjektet, og dermed hele den subjektive forestillingsverden, oppstår i den biologiske kroppen, og virkeliggjøres i kommunikasjon mellom mennesker. Forskning på utviklingen av hjernen hos spedbarn kan fortelle oss at ca. 18 måneder etter fødselen oppstår bevisstheten om et selv, i en kombinasjon av en nevrobiologisk og en relasjonell prosess (3, s. 490-8). I fortsettelsen av det emosjonelle og fysiske samspillet med moren, som begynte allerede før fødselen, begynner barnet på denne tiden å kunne skille mellom seg selv og den andre, det etterlikner den andre, det begynner å kunne delta i en dialog, først ordløst, så ved å forme de universelle babylydene, som så, tilsynelatende plutselig, blir til ord.

Bevisstheten om et eget selv, og så etter hvert ordene, oppstår altså i både en nevrobiologisk og en relasjonell kontekst. Men den relasjonelle delen av dette er ikke bare relasjonell. Den er også det vi, når vi forsøker å sette ord på noe virkelig, vil kalle en etisk kontekst. Den samme forskningen på spedbarnets utvikling kan nemlig også fortelle oss at bevisstheten om eget selv, som senere danner grunnlag for læringen av evnen til å snakke, tenke og resonnere, utvikles i et fysisk og emosjonelt samspill mellom barnet og en omsorgsgiver (som regel først moren) som foregår i en gjensidig innlevelse og tillit $(3$, s. 350-2; 4, 5).

Det faktum at bevisstheten, og språket, oppstår i en etisk kontekst, har implikasjoner for profesjonell hjelp. Det betyr blant annet at det å hjelpe et annet menneske henter en motivasjon som går dypere ned i sinnet enn dit bevisstheten kan nå, det være seg i form av en eksplisitt faglig eller etisk kunnskap, økonomiske incentiver eller strategisk målstyring. Konsekvensene av dette skal jeg komme tilbake til i konklusjonen.

\section{Ordene i verden}

De første ordene vi setter på virkeligheten, vokser frem fra virkeligheten selv, mer presist i den biologiske kroppen, fremkalt av det fysiske og emosjonelle samspillet mellom barn og omsorgsgiver (6). Men deretter danner ordene sin egen verden, som er en kvalitativt annerledes kategori enn den biologiske virkeligheten, nettopp slik både Knausgård og Husserl uttrykker det i sitatene ovenfor. Hvordan kan vi forstå denne forskjellen?

Den tyske matematikeren Georg Cantor (1845-1918) har beskrevet forskjellen mellom virkeligheten og en hvilken som helst beskrivelse av den som både en kvalitativ og en kvantitativ forskjell. Virkeligheten utgjør det vi kaller et kontinuum. Med det menes at den er «sømløst» sammenhengende, i både rom og tid. Enhver beskrivelse av virkelig- 
heten, som kan bestå av ord, sammensetninger av ord, tall og andre symboler, utgjør derimot ikke et kontinuum. Det er snarere enkeltpunkter, plukket ut av denne kontinuerlige virkeligheten, som kan nummereres, gjerne $i$ en uendelig lang liste (som for eksempel hele tallrekken 1, 2, 3 osv. i det uendelige), men like fullt kan alt vi beskriver, beskrives ved en slik nummerert liste.

Det Cantor gjorde (7), var å introdusere et mål på størrelsen av mengder, også de som er uendelig store. Disse målene kalte han kardinaltall. Kardinaltall oppfører seg ikke som vanlige tall, blant annet i uttrykket nedenfor (som for vanlige tall måtte bety at $\mathrm{n}=0$ ). Uttrykket sier noe om forholdet mellom kardinaltallet til et kontinuum, slik som den materielle virkeligheten, og som vi kaller $c$, og kardinaltallet til mengden av alle ord, begreper og symboler som blir laget og satt sammen, med andre ord alt som kan nummereres, og som vi kaller $n$. Dette er, som nevnt, også en uendelig stor mengde, siden tallrekken aldri slutter, men Cantor fant at kardinaltallet $c$ likevel må være større enn kardinaltallet $n$, og ikke bare det, men også at

$$
c-n=c
$$

Sagt med ord sier dette uttrykket at hvis vi fra et kontinuum plukker ut nummererbare elementer, så mange vi bare vil, og gjerne ved hjelp av en metode som trekker ut uendelig mange (for eksempel ved hjelp av en algoritme $i$ et dataprogram), så sitter vi uansett fortsatt tilbake med et kontinuum.

Eller for å bruke Knausgårds ord fra sitatet ovenfor: Det han kaller virkeligheten av andre grad, det vil si alle ordene, er noe alle og enhver, på sin måte, kan «plukke ut» av det han kaller virkeligheten av første grad, den materielle verden. Derfor vil den måten vi gjør det på, være både relativ og forhandlingsbar, som han sier, selv om dette gjøres inne i en virkelighet som er gitt og ikke gjenstand for forhandlinger. Slike «utplukk» kan nemlig gjøres på uendelig mange måter. De ordene vi bruker, har brukt og vil bruke, til alle tider, vil aldri kunne utgjøre mer enn en forsvinnende liten mengde (av nummererbare punkter) i den materielle verden der vi, med Husserls ord, gjør våre «rene og umiddelbare erfaringer» som «objekter blant objekter».

Hva betyr så dette for en profesjonell hjelper, og for forskjellen mellom ham eller henne på den ene siden, og en leder eller en politiker - eller for den saks skyld en forsker - på den andre? En profesjonell hjelper befinner seg til daglig i den samme fysiske virkeligheten som den som skal hjelpes, og gjør det Husserl kaller sine «rene og umiddelbare erfaringer» i denne virkeligheten. Hvis vi fra denne virkeligheten trekker ut enkelte ord som kan skrives, og nummereres, for eksempel i en rapport, et diagnoseskjema eller et budsjett, i en vitenskapelig artikkel eller en lærebok, så er de erfarin-

\section{«De første ordene vi setter på virkelig- heten, vokser frem fra virkeligheten selv»}

gene hjelperen sitter igjen med, og som ikke er kommet med i noen slike rapporter eller skjemaer, artikler eller bøker, fortsatt en «like stor» uendelig erfaringsvirkelighet som de var før disse beskrivelsene ble laget. Det er fordi den profesjonelle hjelperen og den som mottar hjelp, tilhører den samme fysiske virkeligheten, mens rapportene og skjemaene, artiklene og bøkene tilhører en konstruert og nummerert beskrivelse av den samme virkeligheten.

Det som gir profesjonelle hjelpere et fortrinn fremfor ledere, politikerne og forskere, er altså at de til daglig fysisk befinner seg i den samme virkeligheten som de som skal hjelpes. Dermed er de i stand til å forstå de som skal hjelpes, med en større del av det menneskelige potensialet for å forstå noe, enn å være begrenset til den delen av det å forstå noe som bare bruker ord - skriftlig eller muntlig.

\section{Konklusjon}

En lærdom vi kan trekke av dette, er at teoriutvikling i ledelse, politikk og forskning må ha et visst minimum av en felles livsverden med de som befinner seg i det som kalles praksisfeltet, for å kunne være relevant. Faren ligger $i$ at ledere (og politikere og forskere) bruker det meste av sin tid sammen med hverandre, og der konstruerer tankemodeller som lever sine egne liv, mer eller mindre fjernt fra den virkeligheten de handler om. Det som lett kan gå tapt når slike tankemodeller skal styre virkeligheten, er den - ikke-nummererbare - dypereliggende innsikten og motivasjonen som ligger hos den enkelte profesjonelle hjelper, fordi denne strekker seg inn i det som befinner seg bakenfor bevisstheten, nemlig i den kroppslige og etiske konteksten der bevisstheten oppstår. Nettopp fordi den ligger utenfor bevissthetens rekkevidde, er denne innsikten ikke målbar.

Det viktigste for en leder, en politiker eller en forsker blir dermed å ikke være for ivrig med å realisere egne tankemodeller, men heller forsøke å se, frigjøre og forvalte best mulig den energien og den indre motivasjonen som allerede finnes i den enkelte profesjonelle hjelper. Og så langt det er mulig, gå inn i og selv erfare hjelpens daglige virkelighet.

Noen ganger kan det viktigste for en leder - som for leger - være ikke å skade. Å pålegge profesjonelle hjelpere for mange ikke-faglige oppgaver, som rapportering, koordinering og skjemautfylling, eller å presse stadig mer faglig arbeid inn i den tiden som blir igjen, kan ødelegge hjelperens dypereliggende kilde til motivasjon, og dermed virksomhetens viktigste energikilde. Det uheldige er at det er først når dette gjøres, at den økonomiske verdien av denne energikilden blir synlig, men da i form av et tap.

\section{Dag Gjerløw Aasland (f. 1950)}

er professor i økonomi ved Universitetet i Agder hovedinteresse i etikk, og viserektor for forskning ved samme sted 2010-15.

Forfatter har fylt ut ICMJE-skjemaet og oppgir ingen interessekonflikter.

Litteratur

1. Knausgård KO. Om våren. Oslo: Forlaget Oktober 2016.

2. Husserl E. The Crisis of European Sciences and Transcendental Phenomenology. Evanston, Ill. Northwestern University Press, 1970.

3. Schore AN. Affect Regulation and the Origin of the Self: The Neurobiology of Emotional Development. Hillsdale, NJ: Lawrence Erlbaum Associates, 1994

4. Smith L. Foreldres intuitive omsorgsatferd Scandinavian Psychologist 2014: 1. (7.12.2016).

5. Gullestad SE. In the beginning was the affect. Scand Psychoanal Rev 2005; 28: 3-10.

6. Nelson K. Language in cognitive development: The emergence of the mediated mind. Cambridge: Cambridge University Press; 1996.

7. Reed J, Aarnes J. Matematikk i vår tid. Oslo: Universitetsforlaget, 1967.

Mottatt 27.10. 2016, første revisjon innsendt 2.11. 2016, godkjent 14.11. 2016. Redaktør Ketil Slagstad. 